\title{
Prolactin from Pluripotency to Central Nervous System Development
}

\author{
Omar Martínez-Alarcón ${ }^{a}$ Guadalupe García-Lópeza \\ José Raúl Guerra-Mora ${ }^{\mathrm{b}, c}$ Anayansi Molina-Hernández ${ }^{\mathrm{a}}$ \\ Néstor Emmanuel Diaz-Martínez ${ }^{d}$ Wendy Portillo ${ }^{\mathrm{e}}$ Néstor Fabián Díaz ${ }^{\mathrm{a}}$ \\ aDepartamento de Fisiología y Desarrollo Celular, Instituto Nacional de Perinatología, Ciudad de México, \\ Mexico; ${ }^{b}$ Departamento de Neurociencias, Instituto Nacional de Cancerología, Ciudad de México, Mexico; \\ 'Departamento de Cirugia Experimental, Instituto Nacional de Nutrición, Ciudad de México, Mexico; 'Laboratorio \\ de Reprogramación Celular y Bioingeniería de Tejidos, Biotecnología Médica y Farmacéutica CONACYT, Centro de

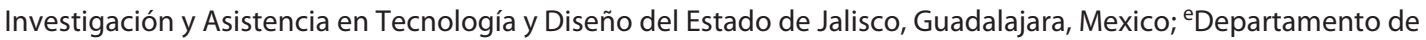 \\ Neurobiología Conductual y Cognitiva, Instituto de Neurobiología, UNAM, Quéretaro, Mexico
}

\section{Keywords}

Stem cells $\cdot$ Embryo development $\cdot$ Reproduction

\section{Abstract}

Prolactin (PRL) is a versatile hormone that exerts more than 300 functions in vertebrates, mainly associated with physiological effects in adult animals. Although the process that regulates early development is poorly understood, evidence suggests a role of PRL in the early embryonic development regarding pluripotency and nervous system development. Thus, PRL could be a crucial regulator in oocyte preimplantation and maturation as well as during diapause, a reversible state of blastocyst development arrest that shares metabolic, transcriptomic, and proteomic similarities with pluripotent stem cells in the naïve state. Thus, we analyzed the role of the hormone during those processes, which involve the regulation of its receptor and several signaling cascades (Jak/Mapk, Jak/Stat, and PI3k/Akt), resulting in either a plethora of physiological actions or their dysregulation, a factor in developmental disorders. Finally, we propose models to improve the knowledge on PRL function during early development.

(c) 2021 S. Karger AG, Basel

\section{Introduction}

Early mammalian development is a complex phenotypic process involving cells that interact with environmental signals that provide instructions such as cellular differentiation, migration, positioning, and maturation. Thus, full-organized organism development begins at the fecundation of a viable egg that progresses to a blastocyst able to produce all body cell types. This capability comprises the pluripotency property. Later, the embryo goes through a postimplantation process with a strictly spatial and temporal regulation. However, the precise role of crucial molecules directing these processes is not elucidated. Multiple extracellular signals, such as hormones, have a relevant function during ontogenesis, that is, growth hormone and placental lactogen. Nonetheless, prolactin (PRL), which belongs to the same family, has not been investigated in depth during embryonic and fetal development.

PRL, similar to growth hormone and placental lactogen, may be involved in critical functions during such stages because of the highly conserved characteristics of this family of peptide hormones, including molecular
Correspondence to:

NestorFabian Diaz,nfdiaz00@yahoo.com.mx 
weight, the number of amino acid residues, and structural homologies. Also, these hormones share analog functions and receptor positions [1]. All these data suggest a role of PRL in the regulation of early vertebrate development. Indeed, excellent reviews on the molecular and physiological functions of PRL centered on postnatal and adult processes (e.g., lactation, reproduction, neuroprotection, and maternal behavior) have been published [2-6]. Thus, despite being a hormone with several physiological actions, scarce information about its role during embryonic and fetal development has been published.

Herein, we analyze the physiological action of PRL during preimplantation stages, that is, oocyte maturation, fecundation and early blastocyst formation, with a focus on pluripotency and diapause. Also, we evaluate its function in neural stem cells during the early nervous system development.

\section{Prolactin and Its Receptor}

\section{Generalities}

PRL is a physiological hormone discovered in 1928 and first reported in 1933 by Riddle et al. [7]. Together with the growth hormone and placental lactogen, PRL belongs to the Class-I helical cytokine superfamily. These cytokines emerged from genetic duplications during early vertebrate evolution and are similar in their exon organization, amino acid sequences, tertiary structures, and receptor-union properties. They also share $25-30 \%$ of their amino acid sequence identity and display considerable differences throughout evolution $[8,9]$. The mouse and human PRL gene (approximate $10 \mathrm{~kb}$ ) are in chromosomes 13 and 6, respectively. It consists of 5 exons and 4 introns, which transcribe a 200 -amino acids peptide with an approximate molecular mass of $23 \mathrm{kDa}$ [10-13]. Two promoters regulate its transcription, the $1 \mathrm{~b}$ exon in the adenohypophysis regulated by Pit1 (PouF1, POU class 1 homeobox 1) and the noncoding 1a exon in extrahypophysis tissues [14-16].

In all species except for fish, the PRL monomer has 3 cysteines related to the formation of 3 disulfide bridges and the result of such interactions produce the secondary structure of the hormone ( $\alpha$-helix united by disulfide bridges and the rest forming loops) (Fig. 1) [14, 17, 18]. Processes like alternative splicing and posttranslational modifications (proteolytic cleavage, dimerization, phosphorylation, and glycosylation) take place during the hormone maturation throughout the endoplasmic reticulum, Golgi apparatus, and secretory granules, impacting the structure and function of the hormone due to changes in receptor affinity and cytosolic distribution $[8,19,20]$.

The hormone exerts over 300 physiological actions, more than all other pituitary hormones combined [14, 21, 22]. This versatility in vertebrates encompasses 6 categories: (1) reproduction and lactation, (2) water and electrolyte balance, (3) morphogenesis and growth, (4) metabolism, (5) behavior, and (6) immunoregulation (Fig. 1) [9, 14, 23].

PRL sources distribute extensively in the anterior pituitary, thymus, spleen, brain, ovaries, myometrium, and decidua. Moreover, the PRL receptor (PRLr) is broadly found in the mammary gland, pancreatic islets, adipose tissue, spleen, and thymus, impacting the development at early stages $[14,24,25]$. The hormone is present in fluids like milk, cerebrospinal fluid, and amniotic fluid during development [16].

PRLr is a single transmembrane protein that belongs to class I of the cytokine receptor superfamily $[14,16,19]$. Its gene is located on chromosomes 6 and 15 in humans and mice, respectively. Mice have 4 PRLr isoforms, 1 long and 3 short (PR-1, PR-2, and PR-3), whereas humans have 5 isoforms, long, intermediate, 2 short, and 1 soluble [26]. Long-, medium-, and short-PRLr isoforms present during the fetal development of mammals, including primates, bovines, and rodents [27-29]. In rodents, the splicing of exons 9-10 results in the generation of the long-isoform receptor mRNA. Whereas the splicing of exon 11 produces $m R N A$ s encoding the short-isoform receptor that contains a distinctive carboxyl terminal. Both isoforms distribute widely in tissues. During mammalian development, the PRLr ligands arise from several sources (e.g., fetal lactotrophs) in the last pregnancy stage. Also, maternal PRLr ligands include the placental lactogen from the trophoblast and PRL secreted by the decidua, among others $[28,29]$. This complex heterogeneity in isoforms and ligands supports a PRLr role in regulating processes during prenatal development, in a similar way in adult animals where the functions of the receptor are widely diversified and the broad PRLr expression corresponds to the physiological actions of the hormone [14]. PRLr expression in fetal or adult tissue depends on the physiological state, age, and cell type [29]. Indeed, changes in the ratio between PRLr isoforms in different tissues can indicate processes like organ/tissue development and maturation, cycle stage, gestation, pathogenesis, and tumor formation [26]. Hence, PRL and its receptor interaction could be vital during early embryo development. However, several aspects are not thoroughly investigated, such as the receptor isoforms and the modification of PRL and PRLr during these stages. 


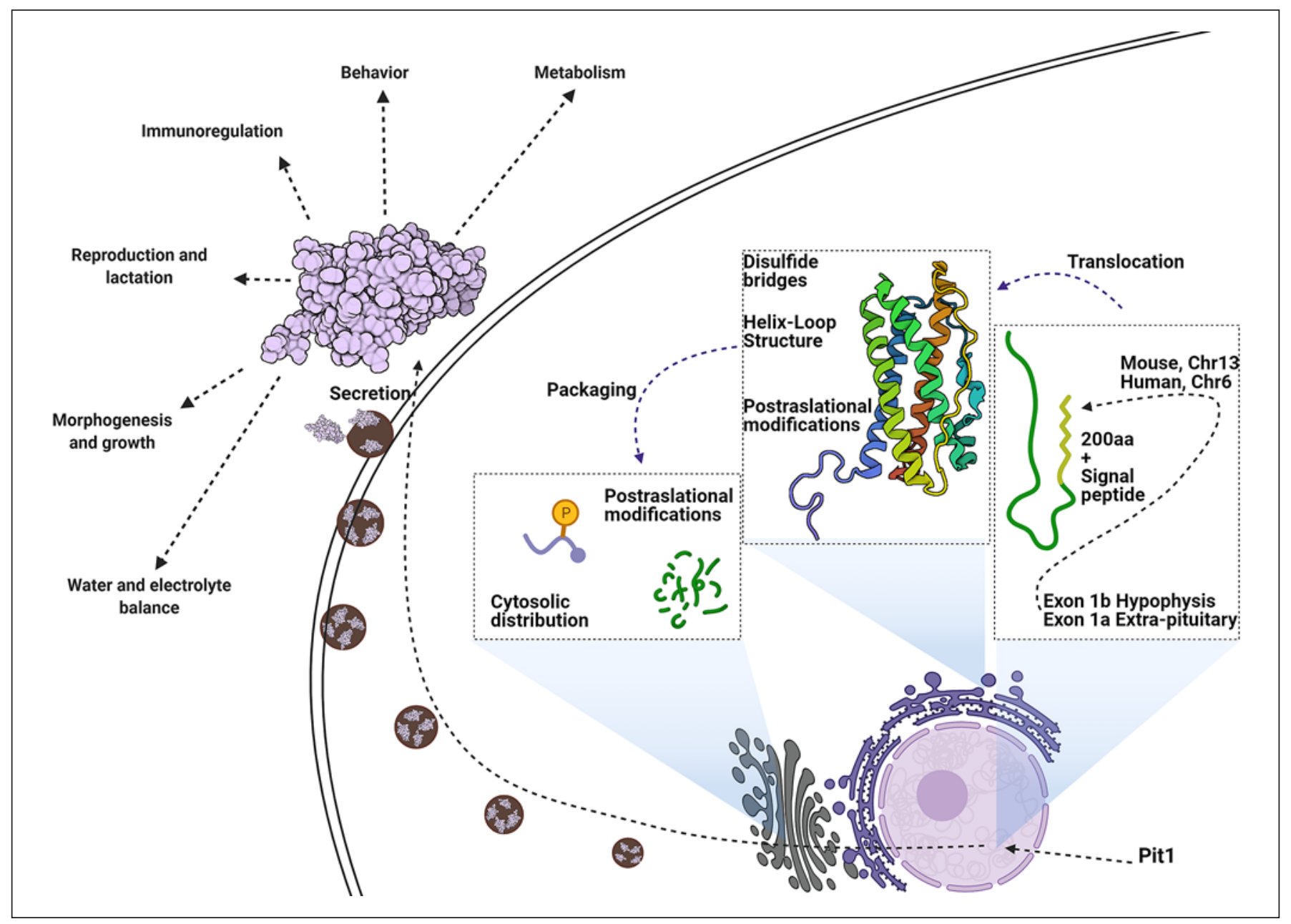

Fig. 1. Biosynthesis and functions of prolactin. Pit1 is a transcription factor involved in the hypophysial synthesis of prolactin; it produces one polypeptide chain (200 aa) plus one signal peptide that allows PRL translocation to the endoplasmic reticulum where the classic helix-loop structure of the hormone is formed and some posttranslational modifications take place. After the packaging, the hormone translocates to Golgi, where modifications, such as phosphorylation, occur. Even in secretory granules, the hormone undergoes processes involved in its maturation before release. The hormone promotes the regulation of several functions on vertebrates. PRL, prolactin.

\section{Oocyte and Preimplantation Development}

\section{Is Prolactin a Key Factor during This Process?}

Diverse factors influence fertilization. Thus, alterations in normal development may produce failure and egg collapse, that is, inappropriate interactions among hormones, growth factors, and cell-cell communication generate mature oocytes that are incompetent for fertilization and incapable of initiating the embryonic preimplantation process. In this scenario, oocytes require nuclear maturation (reversion of meiotic arrest during diplotene of prophase I until shortly before ovulation and again arrested at metaphase II during meiosis II) to pro- mote the extrusion of the first polar body in response to the preovulatory LH surge and cytoplasmic maturation (preparation of the egg for activation and preimplantation development), during which proteins essential to developmental progression are synthesized [30-33]. After fertilization, meiosis II begins with the elimination of the second polar body to complete the maturation process [34].

On the other hand, the 4 PRLr isoforms (1 long and 3 short) are expressed from the oocyte to the blastocyst preimplantation. The short isoforms are present before the 4 -cell stage in mice [35]. In human embryos, PRLr expression has been found from the compaction (process linked 


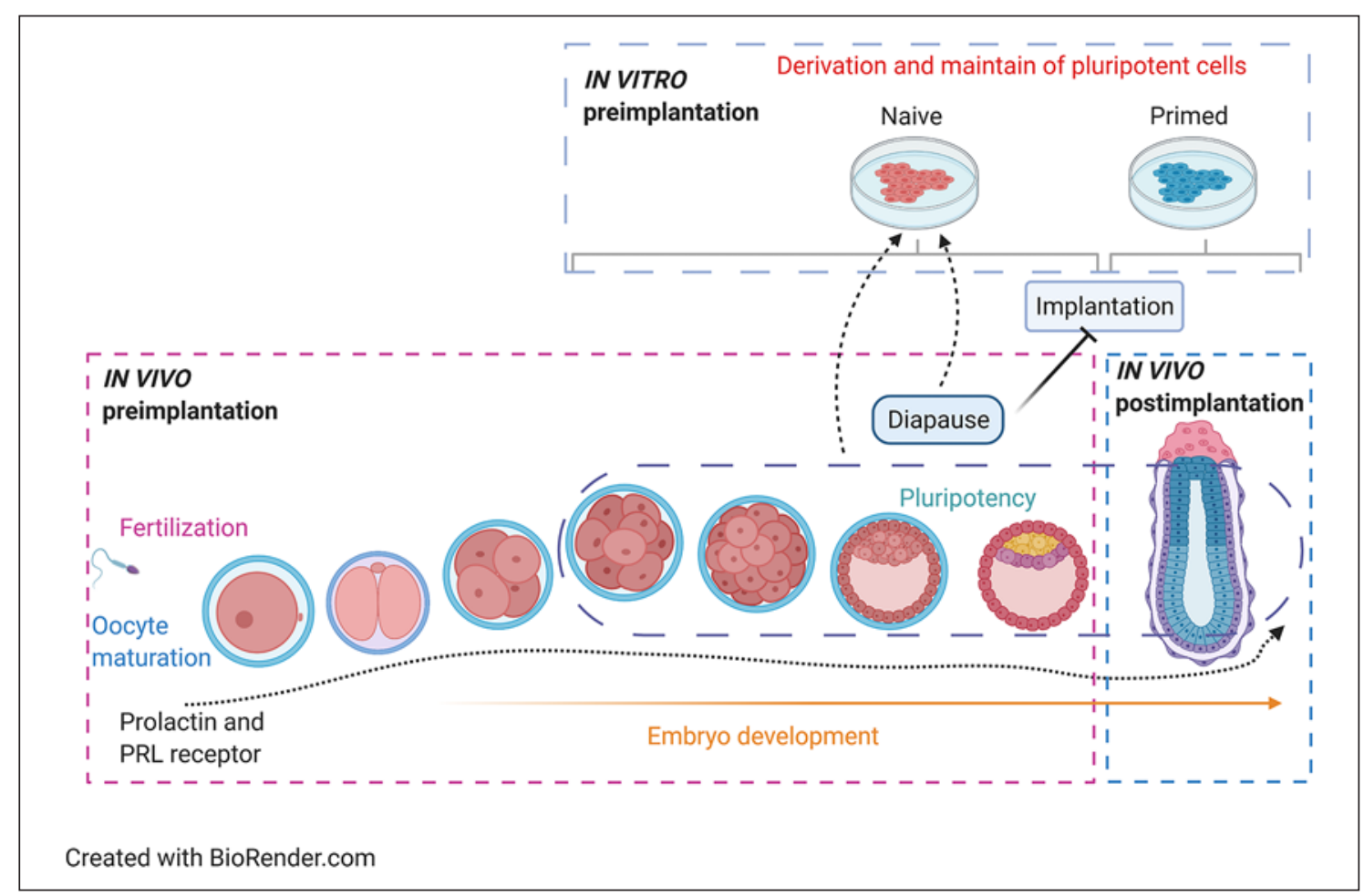

Fig. 2. PRL during early embryo stages and its role in pluripotency. PRL and its receptor (black line dashed) have been found during pre- and postimplantation processes in development. However, their physiological importance is unknown. PRL has also been involved in stopping implantation but maintaining the embryo pluripotency in vivo (diapause) or in vitro (derivation of stem cell lines) or continuing embryo implantation. PRL, prolactin.

to activation of the embryonic genome and considered a good sign of the developmental capacity of the embryo) to the blastula stage [36]. The presence of the receptor and several ligands related to the hormone in the uterine environment before the implantation suggests an essential role of this receptor during the oocyte maturation and preimplantation embryo development [13, 37, 38]. Indeed, PRLR-/- females have multiple abnormalities, few fertilized eggs, oocytes at the germinal vesicle stages released from the ovary, and fragmented embryos, which may be related to oocyte regulation. The number of ovulated eggs decreased, and less than $20 \%$ of the fertilized eggs developed into a blastocyst in mutant compared to wild-type females. Such results were mainly associated with the absence of a long-isoform PRLr, as it is the dominant form present in the reproductive system [39]. Although the predominant PRLr isoform in the adult reproductive system is long, the dynamics and the presence of a predominant isoform in early embryonic development are unknown.

Kiapekou et al. reported that PRL concentrations over $100 \mathrm{ng} / \mathrm{mL}$ in the culture medium increased oocyte matu- ration (percentage of oocytes with the first polar body or germinal vesicles) compared with control and folliclestimulating hormone treatment in mice [40]. A similar result was obtained by Kuz'mina et al. [41], who described that PRL (50 ng) promoted nuclear and cytoplasmic maturation and progression to telophase I and metaphase II. Moreover, supplementation with this hormone in a medium with calf serum increased the development into the morula and blastocyst stages of bovine oocytes cocultured with granulosa cells [41]. The hormone may also interact with its receptor and decelerate the meiotic resumption mechanism (as quantified by cytogenetical techniques) and decrease the oocyte rate with degenerated chromosomes, possibly regulated by tyrosine kinase and nitric oxide synthase (NOS). This phenomenon is associated with crosstalk between L-NAME (NOS inhibitor) and PRL, which suggests a PRL-induced calcium release in the oocytes (determined by fluorometry), essential to activate calcium-dependent isoforms of NOS in bovine oocytes $[42,43]$. However, the specific tyrosine kinase and the complete signaling mechanism are unknown. 
Table 1. Heterogeneity of PRL concentrations and its roles during early development

\begin{tabular}{|c|c|c|c|c|}
\hline Developmental stage/tissue & Concentration of PRL & Effect(s) & Model & Ref. \\
\hline Oocyte & $>100 \mathrm{ng} / \mathrm{mL}$ & Increased maturation & Mouse/in vitro & 18 \\
\hline Oocyte & $50 \mathrm{ng} / \mathrm{mL}$ & Maturation and progression to morula and blastocyst & Bovine/in vitro & 19 \\
\hline Oocyte & $50 \mathrm{ng} / \mathrm{mL}$ & Calcium release & Bovine/in vitro & 20 \\
\hline Oocyte & $10-1000 \mathrm{ng} / \mathrm{mL}$ & Increased blastocyst formation & Rabbit/in vitro & 15 \\
\hline Oocyte & $100 \mathrm{ng} / \mathrm{mL}$ & Increased morula and blastocyst formation & Mouse/in vitro & 36 \\
\hline Blastocyst & $\mathrm{N} / \mathrm{D}$ & Diapause participation & Cynopterus sphinx/in vivo & 45 \\
\hline Endometrium & $\mathrm{N} / \mathrm{D}$ & Switch from diapause to placentation & Capreolus capreolus/in vivo & 46 \\
\hline Blastocyst & $5 \mu \mathrm{g} / \mathrm{mL}$ & Attachment and pluripotent-like cell derivation & Mink/in vitro & 59 \\
\hline Pluripotent stem cell & 0.05 and $0.5 \mu \mathrm{g} / \mathrm{mL}$ & Increased migration and adhesion & Human and mouse & 60 \\
\hline Corpus luteum & $\mathrm{N} / \mathrm{D}$ & Implantation and progesterone secretion & Human & 75,24 \\
\hline Blastocyst & 10 or $20 \mathrm{mIU} / \mathrm{mL}$ & Implantation & Mouse & 76 \\
\hline Human fetus & $>$ PRL control $<$ & Growth retardation and anencephaly & Human & $82-84$ \\
\hline Eyes and brain & Knock-down & Increased apoptosis & Zebrafish & 91 \\
\hline Embryonic neural stem cell & $0.5-500 \mathrm{ng} / \mathrm{mL}$ & Increased proliferation and differentiation & Human & 92 \\
\hline
\end{tabular}

N/D, not determined; PRL, prolactin.

The embryo is exposed to a changing molecular environment, which regulates the first cell divisions and preimplantation development from fecundation (shown in Fig. 2). Dodds and colleagues did not find any effect of PRL in the in vitro fertilization or the cleavage process of mouse oocytes; however, the authors propose that lack of PRL regulation on fertilization or early embryo development did not rule out an effect of the hormone in an in vivo environment [44]. Tesarik and collaborators explored the relationship between steroid, adenohypophysis hormones, cytokine concentrations, and human embryo quality (defined by fragmentation degree and blastomere number) after intracytoplasmic sperm injection. The authors demonstrated that PRL, in conjunction with high luteinizing and growth hormone levels, can enhance the fertilization rate [45]. Nonetheless, Kamel et al. [46] did not find a significant impact of PRL levels (determined by immunoassay) on the prediction of oocyte and embryo quality associated with the fertilization rate. Also, Duan et al. [47] did not find differences between control and hyperprolactinemia groups in the reproductive treatment outcomes (retrieved oocytes, MII oocyte rate, and fertilization); however, the authors suggested that hyperprolactinemia may impact endometrial function and implantation, thus lowering the pregnancy rate. Other studies have explored the associations of PRL levels in women during in vitro fertilization treatments, but the relationship with oocyte maturation, fertilization rate, and embryo development remain elusive [48-51]. Thus, there is controversy about the transient increase in serum PRL levels during the repeated cycles in human-assisted re- production and its possible effect. It would be worth considering that serum PRL levels might not reflect the hormone concentration in the uterine tube and that discrepancy between resident tissue and peripheral hormone concentration might mask its effects (Table 1). Besides, due to the in vivo environment complexity (interactions among several hormones and molecules), the in vitro (experimental) efforts cannot replicate their counterpart; also, reproductive differences between species should be considered.

During early preimplantation development, the endometrium and decidua secrete PRL in the late luteal phase, but its importance in the implantation in mammals remains unknown [52]. PRL concentrations $(10,100$, and $1,000 \mathrm{ng} / \mathrm{mL}$ ) promote an increase in the rate of blastocyst formation, as compared with control, $\mathrm{LH}$, and follicle-stimulating hormone treatment groups when the hormone is applied in cumulus-enclosed rabbit oocytes cultured and fertilized in vitro. The effect on development was dose dependent [31]. Another study showed that PRL (100 ng), through its receptor, enhanced embryonic development of mouse oocytes into morula and blastocyst in vitro, associated with a high cleavage rate [53].

In summary, we hypothesize that PRL promotes oocyte maturation through calcium-regulated mechanisms mediated by its receptor, resulting in meiotic resumption. Hence, the hormone could promote intracellular signals such as second messengers (cAMP or kinases) and lead to calcium release from internal stores. The calcium release inhibition after PRL stimulation or in PRLr KO embryos may explain the role of PRL and its receptor in oocyte 
maturation and fertilization. Hence, PRLr inhibitors and drugs that affect downstream targets may bring a new core of evidence to sustain the PRL role and its receptor in the oocyte maturation.

These data demonstrate the need to in-depth explores the role of PRL and its receptor during early embryonic development and the possible mechanisms involved in their regulation of fertilization. This knowledge may contribute to human reproduction biology and the study of the dynamics of early embryo development in other species.

\section{Diapause: A Stage of Embryo Development when Pluripotency Is Retained}

\section{Prolactin as a Diapause-Orchestrating Hormone}

PRL is a crucial signal to diapause (shown in Fig. 2), a reversible arrest during embryonic development happening mainly at the blastocyst stage, that allows embryonic development to continue when the environmental conditions are safe for offspring survival. In rats and mice, a delay in implantation occurs in lactation, during which the reduction in PRL levels allows blastocyst reactivation [54-56]. Regarding vertebrates, this has been described in poikilothermic animals (fishes such as Nothobranchius, Cynolebias, and Aphyosemion), homeothermic animals (birds like Coturnix and Anseriformes), and mammals (such as Marsupialia, Insectivora, Chiroptera, Edentata, Carnivora, Rodentia, and Artiodactyla). During diapause, the blastocyst either remains quiescent or expands at a prolonged rate (some species retain the zona pellucida, the proactive glycoprotein layer that surrounds the blastocyst) until a specific factor reactivates or induces implantation [57-59]. However, the molecular mechanisms that maintain diapause or reactivation to continue development are poorly understood.

Interestingly, molecular signals involved in diapause have both embryonic and maternal origins. Factors like steroid hormones and PRL have been suggested as essential for diapause and the developmental environment. PRL is critical for luteum maintenance, progesterone production, and implantation, suggesting that PRL regulation may be essential for uterine factors decisive in embryogenesis progression (e.g., estrogen and progesterone) through luteolysis prevention (structural and functional degradation of the corpus luteum) $[39,60]$. Thus, PRL may be an orchestrating molecule through the interaction with progesterone and luteinizing hormone involved in diapause regulation.
Indeed, insufficient progesterone in the preimplantation uterine environment produces pseudopregnancy inability in female PRLr KO-/- mice. They suffer embryo arrest after fertilization, resulting from impaired corpus luteum, which causes oocyte delayed-release and maturation [61]. Important events for the establishment, maintenance, and end of the diapause involve the regulation exerted by PRL. Similarly, Anuradha and Krishna [62] demonstrated PRL participation during delayed embryonic development, regulating the progesterone and estradiol levels associated with luteotropic function in Cynopterus sphinx (short-nosed fruit bat). Korzekwa et al. [63] showed increased progesterone and PRL serum levels, determined by ELISA and mRNA upregulation of the long PRLr isoform, in endometrial tissue during the switch from diapause to placentation in Capreolus capreolus (Roe deer). According to recent studies, PRLr content quantified by PCR is lower during diapause than during reactivation in Mustela vison (mink), the primary animal model used to evaluate diapause, uterus [64]. Also, a decrease in short-isoform PRLr expression in the corpus luteum and uterus-embryonic unity compared with the ovary of Cynopterus sphinx during embryonic diapause using immunohistochemistry and Western blot has been reported [62].

Despite the growing evidence on diapause and its relationship with PRL and its receptor, the possible mechanisms promoting the embryo revival are not fully understood. The importance of PRL in diapause could lay in its ability to regulate key uterine factors in embryogenesis and corpus luteum maintenance or developmental progression. Likewise, the PRLr downregulation in various tissues during diapause could be related to the factors regulated by the hormone and the expression of its receptor, affecting implantation. However, the potential of PRL to be a diapause-orchestrating hormone in some species remains elusive and needs further exploration. An appealing platform to asses this issue is the pluripotent stem cells, described in the next section.

\section{Pluripotency as a Model to Discover the Mystery of Diapause}

Pluripotency is a dynamic, plastic, and progressive continuum state, defined by its ability to differentiate cells into any derivative of the 3 germ layers and self-renew in vitro indefinitely, supported by 2 fundamental identities: naïve and primed (representative of pre- and postimplantation embryo, respectively) (Fig. 2) [65, 66]. Naïve pluripotency is also referred to as the ground state and represents the most homogenous, primitive, and pure plu- 
ripotent potential in the embryo [65, 67]. Experimental manipulation has shown that this cellular potency can be maintained in vitro through the addition of 2 inhibitors of MEK and GSK3 (PD0325901 and CHIR99021, respectively), as well as LIF addition to the media, to establish a molecular environment similar to early development in the inner cell mass/epiblast [68]. Notably, diapause cells of the dormant epiblast have been closely associated with the naïve pluripotency identity because of their proteomic, transcriptomic, and metabolomics profiles [69, 70].

Mouse embryonic stem cells (pluripotent cells derived from the preimplantation embryo) were initially captured from the inner cell mass of mouse blastocysts. These cells had a heterogeneous identity fluctuating between inner cell mass and epiblast when they were cultured with fetal bovine serum and LIF. Interestingly, they were isolated directly from in vitro cultures of mouse blastocysts in a diapause state $[71,72]$. The derivation of pluripotent stem cells may probably be enhanced during diapause, which synchronizes embryos at the naïve stage and promotes an increase in the cell number of the inner cell mass $[71,73]$.

As mentioned, PRL is related to diapause. Thus, the intimate relation of this biostatic state with the pluripotent state opens the possibility that PRL may be a critical factor in the molecular regulation of pluripotency. In accordance, Scognamiglio et al. [74] demonstrated in a series of elegant experiments combining genetic, transcriptomic, and cellular approaches that c-Myc (proto-oncogene related with the cell cycle and metabolism of pluripotent cells) activity reversibly controlled the biosynthetic and proliferative machinery of naïve mouse embryonic stem cells without affecting the three-lineage differentiation capacity and linked these data to the physiological status of dormant diapause embryos. The authors proposed c-Myc as an essential signal for diapause execution because its expression was diminished in embryonic dormancy and its transient inhibition triggered a diapause-alike state on pluripotent cells. c-Myc reestablishment reinitiates the cell cycle in embryos and naïve cells reactivated to continue developing [74]. Also, PRL has been associated with c-Myc expression in W53 lymphoid cells by stimulating its receptor and Src-kinase sequential activation [75]. Hence, PRL might be a c-Myc regulator in pluripotent cells and their evaluation may enable to explain the molecular events that maintain diapause.

Polejaeva et al. [76] determined the role of PRL in diapause and its effects in the pluripotent stem-like cell line derivation (positive to alkaline phosphatase, a classic plu- ripotency marker) from mink. They probed several hormone concentrations on in vitro blastocysts and assessed the attachment and primary colony formation. PRL (5 $\mu \mathrm{g} / \mathrm{mL}$ ) at day 10 induced an increase in the blastocyst attachment and when the hormone was added to the culture medium at days 13-16, it also increased the pluripotent-like cell number. In contrast, 10 ng of hormone diminished the number of both attached blastocyst and pluripotent cell derived; a similar delay was observed in diapause in vivo [76]. Thus, a possible relationship between the uterine environment involving PLR levels and the role of reactivation of diapause blastocysts in vitro might facilitate the establishment of pluripotent cell lines from vertebrate embryos. Sellers and coworkers showed PRLr mRNA in mouse embryonic stem cells (D3), as well as in murine teratocarcinoma (P19) and human embryonal carcinoma (NTera2) pluripotent lines (both derived from early germ-line tumors) by PCR. They also reported that PRLr stimulation-induced Mapk and Akt phosphorylation and treatment with PRL $(0.05$ and $0.5 \mu \mathrm{g} / \mathrm{mL})$ increased migration (chemotaxis) and adhesion of the cell lines to fibronectin plates [77]. These results suggest a relationship of PRL as a regulator of pluripotency.

On the other hand, Jak/Stat, PI3K, Akt, and Erk/Mapk are associated with pluripotency downstream of LIF. Interestingly, these cascades converge with the molecular circuitry regulated by PRL and its receptors [78-80]. Indeed, Mapk and AKT are downstream effectors after forming the heterodimeric receptor complex integrated by LIF and its receptors $\beta$ and gp130 (transmembrane glycoprotein with a cytokine receptor function), which result in Jak phosphorylation in mouse embryonic stem cells $[81,82]$. However, whether Mapk and Akt stimulation by the prolactin pathway is involved in the maintenance of the pluripotency state or related with a change in the molecular identity of the embryonic stem cells linked to lineage commitment, as a change in motility and adhesion (associated with the increased migration), remains unknown $[83,84]$.

Nonetheless, these findings support the hypothesis that pluripotency in vitro and diapause have a set of common factors, which may be regulated by second messengers (mostly unknown) where PRL may be a principal factor. Thus, it is imperative to understand the possible network linking the hormone, diapause, and pluripotency through Jak/Stat or Mapk pathways, pluripotency core genes and the blockade of lineage commitment genes. 


\section{Luteal Development and Implantation}

\section{Prolactin as a Vital Signal}

PRL is involved in trophoblast growth, myometrial contraction regulation, and angiogenesis [85]. However, the distribution and function of this hormone and its receptor during postimplantation development are unclear (shown in Fig. 2).

PRL is one essential signal for the corpus luteum formation and progesterone production [86, 87]. Thus, the increase in progesterone production by the corpus luteum is necessary for blastocyst implantation [88]. PRLr may be required in this process since female KO PRLr-/mice never get pregnant. This completely infertile phenotype presents an increase in serum PRL levels (30-100fold), altered maternal behavior, reduced fat deposition, and impaired function of the corpus luteum $[14,89]$. Although the PRLr absence makes implantation impossible, reimplantation in a PRLr+/+ surrogate mother rescues embryo development. Hence, the PRLr absence in females results in a uterine environment refractory to implantation not associated with the lack of receptors in the oocytes [39]. Such luteal function disturbance is associated with impaired cell-cell interactions between the blastocyst trophectoderm and uterine luminal epithelium, avoiding placental development and pregnancy progression. Interestingly, activation of the long and short PRLr isoforms is essential to establish the corpus luteum through the JAK/STAT5 pathway activation $[61,89,90]$.

Besides, PRL maintains enzymes involved in ester cholesterol turnovers, such as sterol acyltransferase and sterol esterase, which have a role in the luteal tissue, showing the hormone's versatility in implantation [91].

Hyperprolactinemia related to stress during the repeated cycles of in vitro fertilization/intracytoplasmic sperm injection procedures has been linked to an optimal landscape in human implantation, where signals suitable to maintain embryo development are present. Thus, the hormone supports an adequate corpus luteum function promoting progesterone secretion and implantation [46, 92]. Indeed, treatment with PRL, Epidermal Growth Factor and 4-hydroxyestradiol promoted the implantation competency of cultured mouse blastocysts obtained by in vitro fertilization [93]. High endometrial PRL levels disrupted the proliferation of luteinizing granulosa cells and the establishment of corpus luteum providing an abnormal environment for implantation and embryonic development $[14,46,61]$.

These data suggest a possible role of PRL in implantation even though the molecular environment regulation supports the maintenance of the corpus luteum or the signals that attract the embryo to the uterine surface for implantation and early human development. However, the mechanism and the pharmacology of the hormone are unknown, which could open a window to improve human embryo transfers in infertility treatments.

\section{Gastrulation}

\section{The Mystery of Prolactin and Its Receptor}

There is scarce information about PRL and its receptor during the three-lineage establishment in the gastrula. Santos and coworkers show PRLr transcripts and their protein in Sparus aurata tissues obtained from the 3 germ layers, which increase at gastrulation [94]. Nonetheless, there is no strong evidence about the role of PRL and its receptor during the establishment of the 3 germ layers in humans, mice, or other species. In humans and primates, this omission can be explained by the difficulty to obtain the tissue and the ethical-legal limitations. Nevertheless, models like gastruloids (3-dimensional aggregates of pluripotent stem cells that display key features of mammalian development after implantation) $[95,96]$ might be an exciting platform to explore this subject, which is a vital process in the formation of a new organism. Therefore, with models taken from synthetic biology, we could resolve the question about the occurrence of the hormone and its receptor and whether they have a decisive function during embryo development.

\section{Neurulation and Nervous System Development}

\section{Prolactin on Neurogenesis and Neural Stem Cells}

Neurulation is a complex process where the neural tube arises and is regulated by intrinsic and extrinsic signals during which the nervous system primordium is developed. Thus, an adequate signal balance is essential to maintain the neural stem cell (multipotent cells with the capacity to derive neurons and glia) pool and promote the proliferation and differentiation of neurons and glia. In this signal universe, an increased PRL concentration is present from neurulation through nervous system development [97-99]. In mice, the anterior neural tube closes at embryonic day (E) 8.5 and the remaining amniotic fluid in the neural tube forms the cerebrospinal fluid. Thus, the amniotic fluid is the only source of soluble extrinsic factors to command neural stem cells during the early stages of brain development, which has a significant content of PRL $[100,101]$. 
In tissues derived from the 3 germ layers, Royster et al. [27] demonstrated the presence of PRLr during rat fetal development, using in situ hybridization, immunolabeling, and radioligand binding assays. There was an increase from E 17.5 to 20.5, a critical period in the development of the central nervous system, during which migration, gliogenesis, and synaptogenesis occur. Short and long isoforms of the receptor appeared in several nervous system structures, including the olfactory epithelium and the ventricular zone of the cerebral cortex, both neurogenic niches during fetal development. Interestingly, the long isoform was found in the cerebrum but not in the cerebral cortex [27].

During gestational weeks 6-22 in humans and around E16 in mice, the fetus is exposed to high levels of PRL from the endometrium, placenta, and hypophysis. The decidua and probably human amniotic epithelial cells, generate high amounts of PRL. From weeks 12 to 40, during human pregnancy, PRL concentrations in the amniotic fluid tend to be 10-100 times higher than those of maternal and fetal plasma concentrations. Winters et al. [102] determined PRL levels at gestational weeks 16-42 in human fetal plasma by radioimmunoassay. These authors found an increase in plasmatic PRL levels associated with an increment in the adrenal gland weight. However, anencephalic fetuses had lower plasmatic PRL levels than normally developing fetuses, which suggests a possible effect of the hormone on normal development [102]. Arosio et al. [103] found high PRL levels in human fetuses (27-37 weeks) with intrauterine growth retardation and anencephalic fetuses (19-26 weeks) as compared to matched controls. The authors suggested that the proliferative action of PRL may be the physiopathologic mechanism underlying an immature hypothalamic system and insufficient release of dopamine [103]. This observation correlated with the result obtained by Thorpe-Beeston et al. [104], where the PRL levels in fetuses with growth retardation are higher than the controls due to inappropriate maturity of the hypothalamic-pituitary system.

In human fetal hypophysis, Suganuma et al. [105] reported the presence of PRL mRNA from gestational week 16 , reaching a peak at week 27 (11.5 times higher than the average during weeks 16-20). The PRL mRNA expression peak coincides with the neurogenic period, when later born neurons are generated on the cerebral cortex; such neurons reside in the upper cortical layers, particularly dense in humans [106].

Disrupted PRL concentration in mother serum could impact fetal brain growth and lead to neurodevelopmental disorders. Indeed, compared to normal pregnancy

Prolactin during Embryo Development
PRL levels, mild and severe preeclampsia patients show high hormone levels in serum [107]. Thus, pregnancy hypertension disorders increase PRL levels during periods associated with maximum development and fetal growth (i.e., 34 weeks in humans and 150 days in monkey rhesus). These periods are also critical for the brain development of species with a highly developed brain, where later born neuron migration, gliogenesis, and synaptogenesis continue [97, 98, 108-110]. However, there is not a clear correlation between PRL levels during preeclampsia and its possible effects in the cerebral cortex of the newborn.

On the other hand, Nguyen and Zhu [111] reported an effect of PRL in cell survival during early zebrafish development; they knocked down the PRL gene and observed an increase in the apoptotic cell number and a higher expression of the caspase gene compared with the control animals. The apoptotic effect was restricted to the eyes and brain. These data suggest that PRL possibly acts as a cell death regulator by avoiding DNA damage at the central nervous system of the zebrafish embryo [111].

Pathipati et al. [112] determined that large PRL concentrations in the culture medium increased the proliferation and differentiation of human neural stem cells in vitro derived from the fetal cerebral cortex. The hormone treatment increased by 1.2 times the BrdU-positive cell number and the proliferation and differentiation to neuroblast and glial cells compared with the control. Also, during the differentiation process, PRL increased the number of neurons (doublecortin positive) and glial progenitors (S100 $\beta+$ cells) [112]. Therefore, continuously high levels of PRL in the cerebrospinal fluid may promote the development, growth, and differentiation of neural stem cells in early neurogenesis, as observed in adults [113-115]. Also, the short and long isoforms may be associated with neurogenic processes such as neural stem cell regulation at the sub-ventricular zone in the cerebral cortex. Also, the differential expression of isoforms suggests specific pathways involved in the structure development in the nervous system, a notion that will be explored in-depth in the future.

The progressive increase of PRL during pregnancy and the mammalian brain development suggests a connection between the hormone and healthy brain development, orchestrated by maternal PRL during early development and the PRL synthesized by the fetus and mother in later stages. Hence, the proliferative action of PRL might reverberate in neurogenesis during the development and establishment of neural stem cells. An inducible PRLr KO in the neural stem cell might delineate the hormone role 
Fig. 3. Nervous system development and PRL. PRL in the amniotic fluid is one of the most abundant soluble factors during development. Therefore, PRL may have a possible role in regulating neural stem cells. Also, during nervous system development, the hormone levels increase through maternal and fetal synthesis. Hence, the hormone might regulate cell death, migration, gliogenesis, and synaptogenesis. Interestingly, the disturbance in PRL levels is associated with anencephaly. PRL, prolactin.
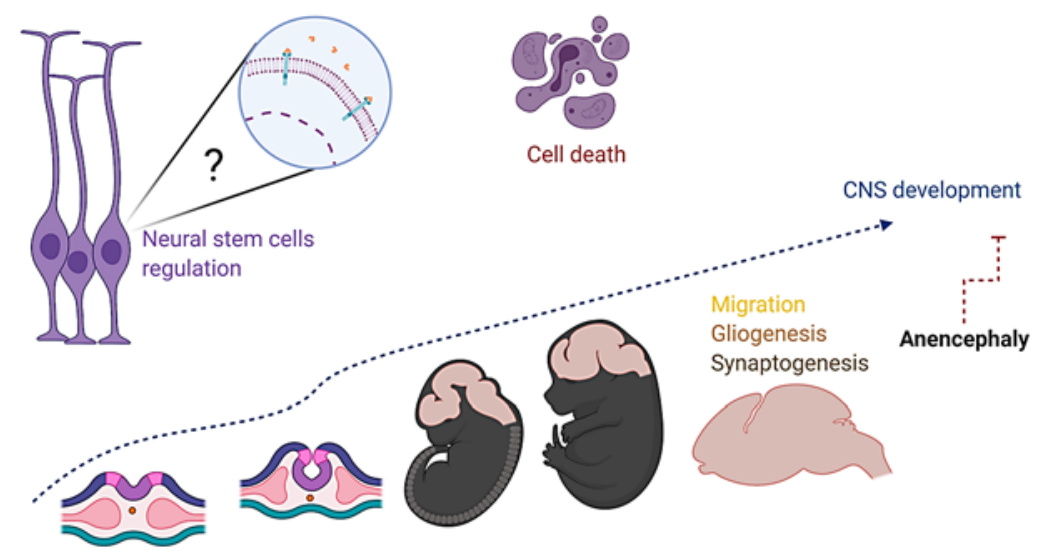

Maternal PRL

Fetal PRL

Created with BioRender.com

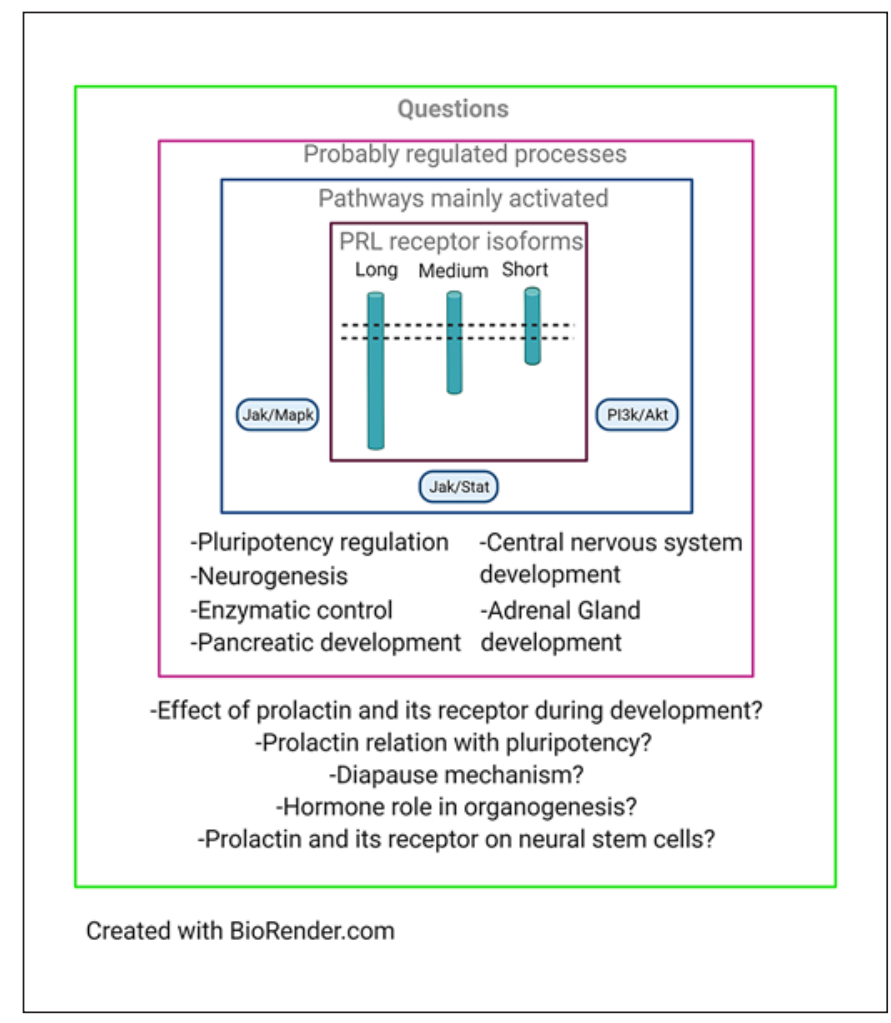

Fig. 4. Quo Vadis of the PRL and its receptor during development. Several questions in which PRL and its receptor might be involved remain unresolved. On this path, specific mechanisms in neurogenesis development and pluripotency remain elusive. PRL, prolactin. in early brain development and neurogenesis. On the other hand, changes in hormonal levels may modify the neurogenesis process (e.g., proliferation, migration, and gliogenesis), thus producing neurodevelopmental disorders like anencephaly (shown in Fig. 3). However, there are limited studies about the impact of PRL on brain development and the regulations of several factors involved in the maintenance and differentiation of neural stem cells and their progeny.

\section{Conclusion}

In this review, we discuss that PRL is an essential hormone with several underexplored roles in early development (shown in Fig. 4). After fecundation, the embryo interacts with a complex hormonal niche where the hormone and its receptor have a potential effect in the first developmental stages. The presence of the PRLr and the hormone in early embryonic developmental stages suggests the intervention of this dyad in the embryonic maturation. However, PRL intervention in the maintenance of pluripotent populations as blastomeres, internal cell mass as well as epiblast and their importance as a chemoattractant signal during implantation remains unexplored.

An underexplored PRL role is its relationship with the derivation of pluripotent stem cells and diapause. To obtain accurate in vitro cell culture conditions is a primary 
goal in the study field of pluripotent stem cells related to the maintenance of the cell properties directly from embryo preimplantation in vivo [116]. It will be relevant to trace additional regulatory cascades that are involved in pluripotency maintenance. To this end, we must know the direct interactions of PRL and its receptor in the underlying signaling pathways in the pluripotent state.

On the other hand, PRL is a hormone associated with neurogenesis in the adult neurogenic niches (the olfactory bulb and the wall of the lateral ventricles) involved in the establishment of paternal behavior [113-115]. Despite the presence of PRL in cerebrospinal and amniotic fluid, it is unknown whether the hormone could interact with neural stem cells during the first stages of central nervous system development and have implications for brain development. Also, the existence of complex interactions of PRLr with other hormones, like placental lactogen and growth hormone, are not discarded, which obscures the PRL role during the development.

It is worthless to mention the limitations in the "state of the art" of PRL and its receptor during development; the vast information originates from classic models and techniques like PCR and in situ hybridization. Thus, it is imperative to employ new technology (RNA seq, KO conditionals, and synthetic biology, among others) to under- stand the essential role of the hormone and its dynamic interaction with environmental signals and growth factors, among others, in specific stages of development and maybe discover 100 other new functions of the hormone.

\section{Acknowledgements}

We thank Jessica Gonzalez Norris and Susana Castro for their excellent technical assistance.

\section{Conflict of Interest Statement}

The authors have no conflicts of interest to disclose.

\section{Funding Sources}

This work was supported by funds from CONACYT A1-S8450 and Instituto Nacional de Perinatologia (212252-321021214-03-16).

\section{Author Contributions}

All authors wrote and edited the manuscript.

\section{References}

1 Newbern D, Freemark M. Placental hormones and the control of maternal metabolism and fetal growth. Curr Opin Endocrinol Diabetes Obes. 2011 Dec;18(6):409-16.

2 Dobolyi A, Oláh S, Keller D, Kumari R, Fazekas EA, Csikós V, et al. Secretion and function of pituitary prolactin in evolutionary perspective. Front Neurosci.. 2020;14:621.

3 Ladyman SR, Hackwell EC, Brown RSJN. The role of prolactin in co-ordinating fertility and metabolic adaptations during reproduction. Neuropharmacology. 2020;167:107911.

4 Lopez\Vicchi F, De Winne C, Brie B, Sorianello E, Ladyman SR, Becu囚Villalobos DJJoN. Metabolic functions of prolactin: physiological and pathological aspects. 2020; 32(11):e12888.

5 Phillipps HR, Yip SH, Grattan DRJM, endocrinology c . Patterns of prolactin secretion. Mol Cell Endocrinol. 2020;502:110679.

6 Molina-Salinas G, Rivero-Segura NA, Cabrera-Reyes EA, Rodríguez-Chávez V, Langley E, Cerbon M. Decoding signaling pathways involved in prolactin-induced neuroprotection: A review. Front Neuroendocrinol. 2021 Mar 22;61:100913.

7 Riddle O, Bates RW, Dykshorn SW. The preparation, identification and assay of prolactin-a hormone of the anterior pituitary.
Am J Physiol Legacy Cont. 1933;105(1):191216.

8 Sinha YN. Structural variants of prolactin: occurrence and physiological significance. Endocr Rev. 1995 Jun;16(3):354-69.

9 Freeman ME, Kanyicska B, Lerant A, Nagy G. Prolactin: structure, function, and regulation of secretion. Physiol Rev. 2000 Oct;80(4): 1523-631.

10 Owerbach D, Rutter WJ, Cooke NE, Martial JA, Shows TBJS. The prolactin gene is located on chromosome 6 in humans. Science. 1981; 212(4496):815-6.

11 Keeler C, Dannies PS, Hodsdon ME, JJomb . The tertiary structure and backbone dynamics of human prolactin. J Mol Biol. 2003; 328(5):1105-21.

12 Wiemers DO, Shao LJ, Ain R, Dai G, Soares MJ. The mouse prolactin gene family locus. Endocrinology. 2003 Jan;144(1):313-25.

13 Brooks CL. Molecular mechanisms of prolactin and its receptor. Endocr Rev. 2012 Aug; 33(4):504-25.

14 Bole-Feysot C, Goffin V, Edery M, Binart N, Kelly PA. Prolactin (PRL) and its receptor: actions, signal transduction pathways and phenotypes observed in PRL receptor knockout mice. Endocr Rev. 1998 Jun;19(3):225-68.

15 Ignacak A, Kasztelnik M, Sliwa T, Korbut RA,
Rajda K, Guzik TJ. Prolactin--not only lactotrophin. A "new" view of the "old" hormone. J Physiol Pharmacol. 2012 Oct;63(5): 435-43.

16 Marano RJ, Ben-Jonathan N. Minireview: Extrapituitary prolactin: an update on the distribution, regulation, and functions. Mol Endocrinol. 2014 May;28(5):622-33.

17 Bewley TA, Li CH. Circular dichroism studies on human pituitary growth hormone and ovine pituitary lactogenic hormone. Biochemistry. 1972 Feb 29;11(5):884-8.

18 Teilum K, Hoch JC, Goffin V, Kinet S, Martial JA, Kragelund BB. Solution Structure of $\mathrm{Hu}-$ man Prolactin. Journal Mol Biol. 2005;351(4): 810-23.

19 Freeman ME, Kanyicska B, Lerant A, Nagy G Prolactin: structure, function, and regulation of secretion. Physiol Rev. 2000 Oct;80(4): 1523-631.

20 Goffin V, Binart N, Touraine P, Kelly PA. Prolactin: the new biology of an old hormone. Annu Rev Physiol. 2002;64:47-67.

21 Niall HD, Hogan ML, Sauer R, Rosenblum IY, Greenwood FC. Sequences of pituitary and placental lactogenic and growth hormones: evolution from a primordial peptide by gene reduplication. Proc Natl Acad Sci U S A. 1971 Apr;68(4):866-70. 
22 Kelly PA, Djiane J, Postel-Vinay MC, Edery M. The prolactin/growth hormone receptor family. Endocr Rev. 1991 Aug;12(3):235-51.

23 Gala RR. Prolactin and growth hormone in the regulation of the immune system. Proc Soc Exp Biol Med. 1991 Oct;198(1):513-27.

24 Rosenberg SM, Maslar IA, Riddick DH. Decidual production of prolactin in late gestation: further evidence for a decidual source of amniotic fluid prolactin. Am J Obstet Gynecol. 1980 Nov 15;138(6):681-5.

25 Gorvin CM. The prolactin receptor: Diverse and emerging roles in pathophysiology. J Clin Transl Endocrinol. 2015 Sep;2(3):85-91.

26 Abramicheva PA, Smirnova OV. Prolactin receptor isoforms as the basis of tissue-specific action of prolactin in the norm and pathology. Biochemistry (Mosc). 2019 Apr;84(4):329-45.

27 Royster M, Driscoll P, Kelly PA, Freemark M. The prolactin receptor in the fetal rat: cellular localization of messenger ribonucleic acid, immunoreactive protein, and ligand-binding activity and induction of expression in late gestation. Endocrinology. 1995 Sep;136(9):3892-900.

28 Schuler LA, Nagel RJ, Gao J, Horseman ND, Kessler MA. Prolactin receptor heterogeneity in bovine fetal and maternal tissues. Endocrinology. 1997 Aug;138(8):3187-94.

29 Schuler LA, Lu JC, Brockman JL. Prolactin receptor heterogeneity: processing and signalling of the long and short isoforms during development. Biochem Soc Trans. 2001 May; 29(Pt 2):52-6.

30 Leibfried-Rutledge ML, Critser ES, Eyestone WH, Northey DL, First NL. Development potential of bovine oocytes matured in vitro or in vivo. Biol Reprod. 1987 Mar;36(2):376-83.

31 Yoshimura Y, Hosoi Y, Iritani A, Nakamura Y, Atlas SJ, Wallach EE. Developmental potential of rabbit oocyte matured in vitro: the possible contribution of prolactin. Biol Reprod. 1989 Jul;41(1):26-33.

32 Eppig JJ. Coordination of nuclear and cytoplasmic oocyte maturation in eutherian mammals. Reprod Fertil Dev. 1996;8(4):485-

33 Keefe D, Kumar M, Kalmbach K. Oocyte competency is the key to embryo potential. Fertil Steril. 2015 Feb;103(2):317-22.

34 Sen A, Caiazza F. Oocyte maturation: a story of arrest and release. Front Biosci (Schol Ed). 2013 Jan 1;5:451-77.

35 Kiapekou E, Loutradis D, Patsoula E, Koussidis GA, Minas V, Bletsa R, et al. Prolactin receptor mRNA expression in oocytes and preimplantation mouse embryos. Reprod Biomed Online. 2005 Mar;10(3):339-46.

36 Ezoe K, Miki T, Ohata K, Fujiwara N, Yabuuchi A, Kobayashi T, et al. Prolactin receptor expression and its role in trophoblast outgrowth in human embryos. 2021.

37 Yohkaichiya T, Fukaya T, Hoshiai H, Yajima A. Improvement of mouse embryo development in vitro by prolactin. Tohoku J Exp Med. 1988 Jul;155(3):241-6.

38 Pantaleon M, Whiteside EJ, Harvey MB, Barnard RT, Waters MJ, Kaye PL. Functional growth hormone $(\mathrm{GH})$ receptors and $\mathrm{GH}$ are expressed by preimplantation mouse embryos: a role for GH in early embryogenesis?. Proc Natl Acad Sci USA. 1997 May 13;94(10):5125-30.

39 Ormandy CJ, Camus A, Barra J, Damotte D, Lucas B, Buteau H, et al. Null mutation of the prolactin receptor gene produces multiple reproductive defects in the mouse. Genes Dev. 1997 Jan 15;11(2):167-78

40 Kiapekou E, Zapanti E, Mastorakos G, Beretsos P, Bletsa R, Drakakis P, et al. Effect of prolactin in the absence of hCG on maturation, fertilization, and embryonic development of in vitro matured mouse oocytes. Ann N Y Acad Sci. 2006 Dec;1092:450-9.

41 Kuz'mina TI, Lebedeva I, Torner H, Alm H. [Effect of prolactin in different culture systems on maturation of bovine oocytes and their ability for further development]. Ontogenez. 2001 Mar-Apr;32(2):140-7.

42 Kuzmina TI, Lebedeva IY, Torner H, Alm H, Denisenko VY. Effects of prolactin on intracellular stored calcium in the course of bovine oocyte maturation in vitro. Theriogenology. 1999 May;51(7):1363-74.

43 Lebedeva IY, Singina GN, Volkova NA, Vejlsted M, Zinovieva NA, Schmidt M. Prolactin affects bovine oocytes through direct and cumulus-mediated pathways. Theriogenology. 2014 Nov;82(8):1154-64.

44 Dodds WG, Fowler J, Peykoff A, Miller KF, Friedman CI, Kim MH. The effect of prolactin on murine in vitro fertilization and embryo development. Am J Obstet Gynecol. 1990 Jun; 162(6):1553-61. discussion 59-61.

45 Mendoza C, Cremades N, Ruiz-Requena E Martinez F, Ortega E, Bernabeu S, et al. Relationship between fertilization results after intracytoplasmic sperm injection, and intrafollicular steroid, pituitary hormone and cytokine concentrations. Hum Reprod. 1999 Mar; 14(3):628-35.

46 Kamel A, Halim AA, Shehata M, AlFarra S, El-Faissal Y, Ramadan W, et al. Changes in serum prolactin level during intracytoplasmic sperm injection, and effect on clinical pregnancy rate: a prospective observational study. BMC Pregnancy Childbirth. 2018 May 9; 18(1):141.

47 Duan Y, Liu X, Hou W, Deng M, Gao J, Zhou C, et al. No impact of treated hyperprolactinemia on cumulative live birth rate and perinatal outcomes in in vitro fertilization-embryo transfer. J Obstet Gynaecol Res. 2019 Jul; 45(7):1236-44

48 Laufer N, Botero-Ruiz W, DeCherney AH, Haseltine F, Polan ML, Behrman HR. Gonadotropin and prolactin levels in follicular fluid of human ova successfully fertilized in vitro. J Clin Endocrinol Metab. 1984 Mar;58(3):4304.

49 Lee MS, Ben-Rafael Z, Meloni F, Mastroianni L Jr., Flickinger GL. Relationship of human oocyte maturity, fertilization, and cleavage to follicular fluid prolactin and steroids. J In Vitro Fert Embryo Transf. 1987 Jun;4(3):16872.
50 Reinthaller A, Deutinger J, Riss P, MullerTyl E, Fischl F, Bieglmayer C, et al. Relationship between the steroid and prolactin concentration in follicular fluid and the maturation and fertilization of human oocytes. J In Vitro Fert Embryo Transf. 1987 Aug;4(4): 228-31.

51 Lindner C, Lichtenberg V, Westhof G, Braendle W, Bettendorf G. Endocrine parameters of human follicular fluid and fertilization capacity of oocytes. Horm Metab Res. 1988 Apr;20(4):243-6.

52 Healy DL. Endometrial prolactin and implantation. Baillieres Clin Obstet Gynaecol. 1991 Mar;5(1):95-105.

53 Kiapekou E, Loutradis D, Mastorakos G, Bletsa R, Beretsos P, Zapanti E, et al. Effect of PRL on in vitro follicle growth, in vitro oocyte maturation, fertilization and early embryonic development in mice. Cloning Stem Cells. 2009 Jun;11(2):293-300.

54 Mantalenakis SJ, Ketchel MM. Frequency and extent of delayed implantation in lactating rats and mice. J Reprod Fertil. 1966 Oct;12(2): 391-4.

55 Flint AP, Renfree MB. Bromocriptine-induced implantation during lactation in the rat. J Reprod Fertil. 1981 May;62(1):181-3.

56 Renfree MB, Fenelon JC. The enigma of embryonic diapause. Development. 2017 Sep 15; 144(18):3199-210.

57 Mead RA. Embryonic diapause in vertebrates. J Exp Zool. 1993 Sep 1;266(6):629-41.

58 Ptak GE, Tacconi E, Czernik M, Toschi P, Modlinski JA, Loi P. Embryonic diapause is conserved across mammals. PLoS One. 2012; 7(3): $\mathrm{e} 33027$.

59 Fenelon JC, Lefevre PL, Banerjee A, Murphy $\mathrm{BD}$. Regulation of diapause in carnivores. Reprod Domest Anim. 2017 Apr;52(Suppl 2): 12-7.

60 Grosdemouge I, Bachelot A, Lucas A, Baran N, Kelly PA, Binart N. Effects of deletion of the prolactin receptor on ovarian gene expression. Reprod Biol Endocrinol. 2003 Feb 6; $1: 12$.

61 Binart N, Helloco C, Ormandy CJ, Barra J, Clement-Lacroix P, Baran N, et al. Rescue of preimplantatory egg development and embryo implantation in prolactin receptor-deficient mice after progesterone administration. Endocrinology. 2000 Jul;141(7):2691-7.

62 Anuradha, Krishna A. Prolactin modulates luteal activity in the short-nosed fruit bat, Cynopterus sphinx during delayed embryonic development. Gen Comp Endocrinol. 2017 Jul 1;248:27-39.

63 Korzekwa AJ, Kotlarczyk AM, Zadroga A. Profiles of maternal origin factors during transition from embryonic diapause to implantation in roe deer. Anim Sci J. 2019 Nov; 90(11):1444-52.

64 Fenelon JC, Banerjee A, Lefevre P, Gratian F, Murphy BD. Polyamine-mediated effects of prolactin dictate emergence from mink obligate embryonic diapause. Biol Reprod. 2016 Jul;95(1):6. 
65 Nichols J, Smith A. Naive and primed pluripotent states. Cell Stem Cell. 2009 Jun 5;4(6): 487-92.

66 Avila-Gonzalez D, Garcia-Lopez G, GarciaCastro IL, Flores-Herrera H, Molina-Hernandez A, Portillo W, et al. Capturing the ephemeral human pluripotent state. Dev Dyn. 2016 Jul;245(7):762-73.

67 Boroviak T, Loos R, Bertone P, Smith A, Nichols J. The ability of inner-cell-mass cells to self-renew as embryonic stem cells is acquired following epiblast specification. Nat Cell Biol. 2014 Jun;16(6):516-28.

68 Ying QL, Wray J, Nichols J, Batlle-Morera L, Doble B, Woodgett J, et al. The ground state of embryonic stem cell self-renewal. Nature. 2008 May 22;453(7194):519-23.

69 Boroviak T, Loos R, Lombard P, Okahara J, Behr R, Sasaki E, et al. Lineage-specific profiling delineates the emergence and progression of naive pluripotency in mammalian embryogenesis. Dev Cell. 2015 Nov 9;35(3):366-82.

70 Chandrasekaran S, Zhang J, Sun Z, Zhang L, Ross CA, Huang YC, et al. Comprehensive mapping of pluripotent stem cell metabolism using dynamic genome-scale network modeling. Cell Rep. 2017 Dec 5;21(10):2965-77.

71 Evans MJ, Kaufman MH. Establishment in culture of pluripotential cells from mouse embryos. Nature. 1981 Jul 9;292(5819):154-6.

72 Riveiro AR, Brickman JM. From pluripotency to totipotency: an experimentalist's guide to cellular potency. Development. 2020 Aug 26; 147(16): 147.

73 Nichols J, Smith A. Pluripotency in the embryo and in culture. Cold Spring Harb Perspect Biol. 2012 Aug 1;4(8):a008128.

74 Scognamiglio R, Cabezas-Wallscheid N, Thier MC, Altamura S, Reyes A, Prendergast AM, et al. Myc depletion induces a pluripotent dormant state mimicking diapause. Cell. 2016 Feb 11;164(4):668-80.

75 Dominguez-Caceres MA, Garcia-Martinez JM, Calcabrini A, Gonzalez L, Porque PG, Leon J, et al. Prolactin induces c-Myc expression and cell survival through activation of Src/Akt pathway in lymphoid cells. Oncogene. 2004 Sep 23;23(44):7378-90.

76 Polejaeva IA, Reed WA, Bunch TD, Ellis LC, White KL. Prolactin-induced termination of obligate diapause of mink (Mustela vison) blastocysts in vitro and subsequent establishment of embryonic stem-like cells. J Reprod Fertil. 1997 Mar;109(2):229-36.

77 Sellers ZP, Bujko K, Schneider G, Kucia M, Ratajczak MZ. Novel evidence that pituitary sex hormones regulate migration, adhesion, and proliferation of embryonic stem cells and teratocarcinoma cells. Oncol Rep. 2018 Feb;39(2):851-9.

78 Hirai H, Karian P, Kikyo N. Regulation of embryonic stem cell self-renewal and pluripotency by leukaemia inhibitory factor. Biochem J. 2011 Aug 15;438(1):11-23.

79 Radhakrishnan A, Raju R, Tuladhar N, Subbannayya T, Thomas JK, Goel R, et al. A pathway map of prolactin signaling. J Cell Commun Signal. 2012 Aug;6(3):169-73.
80 Zhao H, Jin Y. Signaling networks in the control of pluripotency. Curr Opin Genet Dev. 2017 Oct; $46: 141-8$

81 Niwa H, Ogawa K, Shimosato D, Adachi K. A parallel circuit of LIF signalling pathways maintains pluripotency of mouse ES cells. Nature. 2009 Jul 2;460(7251):118-22.

82 Martello G, Bertone P, Smith A. Identification of the missing pluripotency mediator downstream of leukaemia inhibitory factor. EMBO J. 2013 Oct 2;32(19):2561-74.

83 Kunath T, Saba-El-Leil MK, Almousailleakh M, Wray J, Meloche S, Smith A. FGF stimulation of the Erk1/2 signalling cascade triggers transition of pluripotent embryonic stem cells from self-renewal to lineage commitment. Development. 2007 Aug;134(16):2895-902.

84 Veluscek G, Li Y, Yang SH, Sharrocks AD. Jun-mediated changes in cell adhesion contribute to mouse embryonic stem cell exit from Ground State Pluripotency. Stem Cells. 2016 May;34(5):1213-24.

85 Jabbour HN, Critchley HO. Potential roles of decidual prolactin in early pregnancy. Reproduction. 2001 Feb;121(2):197-205.

86 Murphy BD, Rajkumar K. Prolactin as a luteotrophin. Can J Physiol Pharmacol. 1985 Mar;63(3):257-64.

87 Richardson DW, Goldsmith LT, Pohl CR, Schallenberger E, Knobil E. The role of prolactin in the regulation of the primate corpus luteum. J Clin Endocrinol Metab. 1985 Mar; 60(3):501-4.

88 Mesen TB, Young SL. Progesterone and the luteal phase: a requisite to reproduction. $\mathrm{Ob}$ stet Gynecol Clin North Am. 2015 Mar;42(1): 135-51.

89 Kelly PA, Binart N, Lucas B, Bouchard B, Goffin V. Implications of multiple phenotypes observed in prolactin receptor knockout mice. Front Neuroendocrinol. 2001 Apr; 22(2): $140-5$

90 Le JA, Wilson HM, Shehu A, Mao J, Devi YS, Halperin J, et al. Generation of mice expressing only the long form of the prolactin receptor reveals that both isoforms of the receptor are required for normal ovarian function. Biol Reprod. 2012 Mar;86(3):86.

91 Behrman HR, Orczyk GP, Macdonald GJ, Greep RO. Prolactin induction of enzymes controlling luteal cholesterol ester turnover. Endocrinology. 1970 Dec;87(6):1251-6.

92 Majumdar A, Mangal N. Hyperprolactinemia. J Hum Reprod Sci. 2013 Jul;6(3): 168-75.

93 Takeuchi M, Seki M, Furukawa E, Takahashi A, Saito K, Kobayashi M, et al. Improvement of implantation potential in mouse blastocysts derived from IVF by combined treatment with prolactin, epidermal growth factor and 4-hydroxyestradiol. Mol Hum Reprod. 2017 Aug 1;23(8):557-70.

94 Santos C, Cavaco J, Ingleton P, Power DJG, endocrinology c. Developmental ontogeny of prolactin and prolactin receptor in the sea bream (Sparus aurata). Gen Comp Endocrinol. 2003;132(2):304-14
95 van den Brink SC, Baillie-Johnson P, Balayo T, Hadjantonakis AK, Nowotschin S, Turner DA, et al. Symmetry breaking, germ layer specification and axial organisation in aggregates of mouse embryonic stem cells. Development. 2014 Nov; 141(22):4231-42

96 Deglincerti A, Etoc F, Guerra MC, Martyn I, Metzger J, Ruzo A, et al. Self-organization of human embryonic stem cells on micropatterns. Nat Protoc. 2016;11(11):2223-32.

97 Seron-Ferre M, Monroe SE, Hess D, Parer JT, Jaffe RB. Prolactin concentrations in the monkey fetus during the last third of gestation. Endocrinology. 1979 May; 104(5): $1243-6$.

98 Freemark M. Ontogenesis of prolactin receptors in the human fetus: roles in fetal development. Biochem Soc Trans. 2001 May; 29(Pt 2):38-41.

99 Ogasawara K, Nogami H, Tsuda MC, Gustafsson JA, Korach KS, Ogawa S, et al. Hormonal regulation of prolactin cell development in the fetal pituitary gland of the mouse. Endocrinology. 2009 Feb;150(2): 1061-8.

100 Zappaterra MW, Lehtinen MK. The cerebrospinal fluid: regulator of neurogenesis, behavior, and beyond. Cell Mol Life Sci. 2012 Sep;69(17):2863-78.

101 Chau KF, Springel MW, Broadbelt KG, Park HY, Topal S, Lun MP, et al. Progressive differentiation and instructive capacities of amniotic fluid and cerebrospinal fluid proteomes following neural tube closure. Dev Cell. 2015 Dec 21;35(6):789-802.

102 Winters AJ, Colston C, MacDonald PC, Porter JC. Fetal plasma prolactin levels. J Clin Endocrinol Metab. 1975 Sep;41(3):626-9.

103 Arosio M, Cortelazzi D, Persani L, Palmieri E, Casati G, Baggiani AM, et al. Circulating levels of growth hormone, insulin-like growth factor-I and prolactin in normal, growth retarded and anencephalic human fetuses. J Endocrinol Invest. 1995 May; 18(5):346-53.

104 Thorpe-Beeston JG, Snijders RJ, Felton CV Nicolaides KH. Serum prolactin concentration in normal and small for gestational age fetuses. Br J Obstet Gynaecol. 1992 Dec; 99(12):981-4

105 Suganuma N, Seo H, Yamamoto N, Kikkawa F, Narita O, Tomoda Y, et al. Ontogenesis of pituitary prolactin in the human fetus. J Clin Endocrinol Metab. 1986 Jul;63(1): 156-61.

106 Lui JH, Hansen DV, Kriegstein AR. Development and evolution of the human neocortex. Cell. 2011 Jul 8;146(1):18-36.

107 Leanos-Miranda A, Marquez-Acosta J, Cardenas-Mondragon GM, Chinolla-Arellano ZL, Rivera-Leanos R, Bermejo-Huerta $S$, et al. Urinary prolactin as a reliable marker for preeclampsia, its severity, and the occurrence of adverse pregnancy outcomes. J Clin Endocrinol Metab. 2008 Jul;93(7): 2492-9. 
108 Symonds ME, Mostyn A, Stephenson T. Cytokines and cytokine receptors in fetal growth and development. Biochem Soc Trans. 2001 May;29(Pt 2):33-7.

109 Pearce S, Mostyn A, Alves-Guerra MC, Pecqueur C, Miroux B, Webb R, et al. Prolactin, prolactin receptor and uncoupling proteins during fetal and neonatal development. Proc Nutr Soc. 2003 May;62(2):421-7.

110 Silbereis JC, Pochareddy S, Zhu Y, Li M, Ses$\tan \mathrm{N}$. The cellular and molecular landscapes of the developing human central nervous system. Neuron. 2016 Jan 20;89(2):248-68.
111 Nguyen N, Zhu Y. Prolactin functions as a survival factor during zebrafish embryogenesis. Comp Biochem Physiol A Mol Integr Physiol. 2009 May;153(1):88-93.

112 Pathipati P, Gorba T, Scheepens A, Goffin V, Sun Y, Fraser M. Growth hormone and prolactin regulate human neural stem cell regenerative activity. Neuroscience. 2011 Sep 8;190:409-27.

113 Shingo T, Gregg C, Enwere E, Fujikawa H, Hassam R, Geary C, et al. Pregnancy-stimulated neurogenesis in the adult female forebrain mediated by prolactin. Science. 2003 Jan 3;299(5603):117-20.
114 Mak GK, Enwere EK, Gregg C, Pakarainen T, Poutanen M, Huhtaniemi I, et al. Male pheromone-stimulated neurogenesis in the adult female brain: possible role in mating behavior. Nat Neurosci. 2007 Aug;10(8): 1003-11.

115 Mak GK, Weiss S. Paternal recognition of adult offspring mediated by newly generated CNS neurons. Nat Neurosci. 2010 Jun;13(6): 753-8.

116 Ying QL, Smith A. The art of capturing pluripotency: creating the right culture. Stem Cell Rep. 2017 Jun 6;8(6):1457-64. 